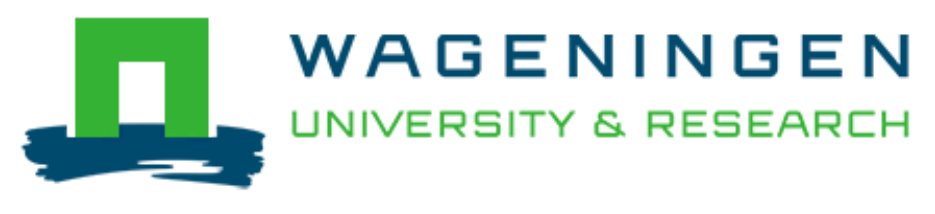

\author{
A framework to estimate biodiversity loss and associated costs due to \\ nitrogen emissions from single power plants \\ Verburg, R. W., \& Osseweijer, F.
}

This is a "Post-Print" accepted manuscript, which has been Published in "Journal of Cleaner Production"

This version is distributed under a non-commercial no derivatives Creative Commons (c) (1) @ ( 9 (CC-BY-NC-ND) user license, which permits use, distribution, and reproduction in any medium, provided the original work is properly cited and not used for commercial purposes. Further, the restriction applies that if you remix, transform, or build upon the material, you may not distribute the modified material.

Please cite this publication as follows:

Verburg, R. W., \& Osseweijer, F. (2019). A framework to estimate biodiversity loss and associated costs due to nitrogen emissions from single power plants. Journal of Cleaner Production, 239, [117953]. https://doi.org/10.1016/j.jclepro.2019.117953

You can download the published version at:

https://doi.org/10.1016/j.jclepro.2019.117953 


\title{
A framework to estimate biodiversity loss and associated costs due to nitrogen emissions from single power plants
}

René W. Verburg ${ }^{1,2, a}$ and Floor Osseweijer ${ }^{1}$

1: Copernicus Institute of Sustainable Development, Utrecht University, Princetonlaan 8a, 3584 CB Utrecht, The Netherlands

2: Wageningen Economic Research, PO Box 29703, 2502 LS Den Haag, the Netherlands

a: corresponding author, r.w.verburg@uu.nl, tel. +31302537470

\begin{abstract}
Environmental reporting by companies is becoming increasingly important for measuring sustainability performance, but biodiversity impacts are still largely unaccounted for due to the complexity of assessing such impacts. Energy production by power plants causes nitrogen emissions that may affect nature areas. To assess the impact of power plants on the biodiversity of Natura 2000 areas and to estimate compensation costs, we developed an analytical framework and applied it to four single power plants in the Netherlands. These plants differed according to production capacity and fuel source (natural gas and biomass). The plants affected between 77 and $537 \mathrm{~km}^{2}$ of Natura 2000 nature areas. To estimate cost of biodiversity loss and compensation, three approaches were applied: costs of restoration, 'insetting' costs incurred by creating new nature areas within the current Natura 2000 network, and offsetting costs, including land purchase of former agricultural land. Depending on the nitrogen exceedance levels of vegetation, compensation areas ranged between 6.5 and 23.6 ha. The estimated total cost per power plant varied from $€ 38,430$ to $€ 1,753,261$ annually. Depending on the cost method applied, biodiversity cost of energy production by single power plants ranged from $0.06 €$. MWh-1 to $1.65 €$. MWh ${ }^{-1}$. This cost largely depends on the type and location of the vegetation affected, which indicates that a spatial analysis is needed to measure the biodiversity footprint of business operations in environmental reporting.
\end{abstract}




\section{Key words}

Biodiversity, compensation costs, energy production, nitrogen emissions

\section{Introduction}

Biodiversity loss is one of the most pressing environmental issues worldwide, alongside and interlinked with climate change (Rockström et al., 2009; Steffen et al., 2015). For example, natural habitats are impacted by nitrogen deposition through eutrophication, toxicity and acidification, leading to biodiversity loss (Dise et al., 2011). Over the years, anthropogenic nitrogen emissions have developed from a relatively unimportant source to a major source of nitrogen influx into ecosystems. Global annual ammonia emissions have been estimated at $53.7 \mathrm{Tg}$ $\mathrm{N}$, of which approximately $20 \%$ is of natural origin (Carnell et al., 2017; Dise et al., 2011; Erisman et al., 2007; Stevens et al., 2011; Sutton et al., 2014). Energy and food production are the main sources of reactive nitrogen while agriculture accounts for about $40 \%$ of total ammonia and nitrate emissions (Carnell et al., 2017; Erisman et al., 2007; Kros et al., 2013; Tan et al., 2018). Bobbink et al. (2010) and Stevens (2016) showed that nitrogen accumulation is the main driver of changes to plant communities across different ecosystems. Excess nitrogen initially increases the herbaceous cover with nitrophilous species, but nitrogen-efficient species tend to disappear, leading to species loss (Bobbink et al., 2010; Stevens, 2016; Stevens et al., 2011). Due to high nitrogen emissions, the conservation status of European nature areas is still unfavourable, more than 25 years after the implementation of the Habitats Directive (Council Directive 92/43/EEC) and 40 years after the Birds Directive (Council Directive 79/409/EEC). The 'health check' carried out by the European Commission in 2006 indicated that about $80 \%$ of the habitat types are still under threat (Commission of the European Communities, 2009; Schoukens and Cliquet, 2016).

In the context of the European Natura 2000 Network (Commission of the European Communities, 2009), habitat types have been classified in terms of their critical deposition loads (CDL) (Kuylenstierna et al., 1998; Sutton et al., 2014; Van Dobben et al., 2006; Vivanco et al., 2018). The CDL reflects "the limit above which there is a risk that the quality of the habitat will significantly be affected by atmospheric nitrogen deposition" (Van Dobben et al., 2006).

Recent developments in governmental agencies, NGOs and business have led to the introduction of voluntary commitments aimed at reducing biodiversity loss and maintaining ecosystem services in 
natural areas (Wende et al., 2018). Many businesses nowadays incorporate a sustainability strategy to lower the impact of their activities on the environment (Eidelwein et al., 2018; Jose and Lee, 2007). Such strategies often result in so-called 'management of environmental disclosure', which can be defined as a set of methods applied by businesses to disclose environmental responsibilities to their stakeholders and shareholders (Brown et al., 2009; Rosa et al., 2012).

Increasingly, corporate responsibility is also developing beyond environmental disclosure (Clift et al., 2017; Sabag Muñoz and Gladek, 2017). According to Thébaud et al. (2015) and Apostolopoulou (2016), corporate activities should strive for so-called 'no-net-loss' and 'no-netimpact' strategies. This has led to the One Planet Approach, a framework to measure and reduce human impact to a level that remains within planetary boundaries (Clift et al., 2017; Sabag Muñoz and Gladek, 2017; Sandin et al., 2015). To effectuate no-net-loss, mitigation hierarchies should be applied to avoid damage, followed by compensation and offsetting if mitigation is not possible (Bull et al., 2013; Quétier and Lavorel, 2011). The irreversibility of many ecological processes, thresholds and limits to offsets, and inclusiveness of cumulative effects are major issues that need to be dealt with (Quétier and Lavorel, 2011).

Environmental pressures often have localized effects (Moslehi and Reddy, 2019), leading to biodiversity impacts on various spatial scales (Bidstrup et al., 2015). Therefore, assessments need to take these localized effects into account to make the disclosure of biodiversity impacts, henceforth referred to as the biodiversity footprint, credible and legitimate (Brooks et al., 2016). This requires a better understanding of the complex relationships between pressures and the spatial distribution of biodiversity footprints (Sandin et al., 2015). Moreover, habitat compensation also suggests expressing the impacts of business activities on the natural environment in monetary values (Bull et al., 2013; Nunes and van den Bergh, 2001; Sijtsma et al., 2017).

In the energy sector, the combustion of fuels to produce electricity causes nitrogen emissions (Vijayaraghavan et al., 2010) with concomitant negative effects on biodiversity. Although life cycle assessments (LCA) of the energy sector have been applied for land and material use (Curran et al., 2011; Eksi and Karaosmanoglu, 2018; Verones et al., 2015), this has been done much less for the localized contexts of operational impacts (Klöpffer and Curran, 2016). 
Due to the indirect biodiversity effects, creating a practical tool that enables businesses to identify the biodiversity footprint is a major challenge (Curran et al., 2011). This issue has been investigated over the past few years, leading to the development of various biodiversity impact assessment methods with different underlying principles, indicators and offset or compensation options (Curran et al., 2011; Huijbregts et al., 2001; Marques et al., 2017; Quétier and Lavorel, 2011). However, these methods have not always led to better environmental disclosure (Haffar and Searcy, 2018; Skouloudis et al., 2019). For this reason, in this paper we introduce a methodology to assess the biodiversity footprint, caused by the nitrogen emissions of individual power plants. We apply the methodology to a selection of power plants, to assess the contribution of these plants to the spatial biodiversity footprint in Natura 2000 nature areas in the Netherlands. This contribution is further assessed in terms of both nature-compensation area and associated compensation costs as a result of these negative impacts. Such compensation costs may reflect the monetary value of the biodiversity footprint.

\section{Methods}

Our analytical framework is based on previous work by Quétier and Lavorel (2011), Gardner et al. (2013), Bull et al. (2013), and Pilgrim and Ekstrom (2014) to contextualize site-specific ecosystem states and biodiversity impacts, and is presented in Figure 1. The framework takes into account both the pressures of a single power plant and pressures from other economic activities. The steps in the framework include assessing emission loads (section 2.1), emission modelling (section 2.2), identifying nature areas and estimating biodiversity impacts (section 2.3), calculating monetary compensation (section 2.4) and performing a sensitivity analysis of the parameter estimates (section 2.5).

\subsection{Emission loads}

We applied the framework to four power plants in the Netherlands that vary in type of energy conversion and geographic location (Table 1, Figure 2). Site visits were made to understand the specifics of the plants. All site-specific information used in the study was gathered from the annual environmental reports. Power plants 1-3 have combined-cycle gas turbines for electricity and heat production using natural gas, while Plant 4 is a biomass plant for electricity and heat production. 
Plant 3 is a combined emission source of two gas turbines, an auxiliary boiler, two back-up boilers and a boiler station. Emission loads of all point sources of this power plant were added up. The heights of the emission sources were $64 \mathrm{~m}$ for Plants 1 and 2, $55 \mathrm{~m}$ for the gas turbines of Plant 3 (and 3-8 $\mathrm{m}$ for the back-up power and water boiler stations of Plant 3), and $80 \mathrm{~m}$ for Plant 4 . For all power plants, the annual nitrogen emissions of 2015 were used for analysis (see Table 1).

\subsection{Nitrogen emission and deposition modelling}

Nitrogen emissions are deposited at various spatial scales, ranging from $100 \mathrm{~m}$ up to more than $200 \mathrm{~km}$ (e.g. van der Swaluw et al., 2017). To define the impact area of nitrogen emissions, the location of an emitting source is needed (van der Swaluw et al., 2017). The Dutch National Institute of Public Health and the Environment (RIVM) has developed the publicly available AERIUS web-tool to estimate nitrogen deposition from agricultural activities, which we applied to the power plants (e.g. de Heer et al., 2017; Sauter et al., 2011; Van der Swaluw et al., 2017; Wichink Kruit et al., 2017; see https://www.aerius.nl/en). AERIUS is a suite of tools that includes spatial maps, while deposition calculations are based on the Operational Priority Substances (OPS) model (Sauter et al., 2011; Wichink Kruit et al., 2017). The OPS model in AERIUS is confined to impacts of nitrogen emissions on Natura 2000 sites only. As our analysis is restricted to these sites, it must be noted that non-Natura 2000 areas will also be affected. AERIUS was used to identify the Natura 2000 sites on which nitrogen was deposited, taking into account the point source location, wind direction, terrain roughness and deposition levels from $0.05 \mathrm{Mol} \mathrm{N} \cdot \mathrm{ha}^{-1} \cdot \mathrm{yr}^{-1}$ upwards (Sauter et al., 2011; Wichink Kruit et al., 2017). This lower limit was defined by considering that additional deposition of $<1 \mathrm{~kg} \mathrm{~N} \cdot \mathrm{ha}^{-1} \cdot \mathrm{yr}^{-1}\left(\approx 70 \mathrm{Mol} \mathrm{N} \cdot \mathrm{ha}^{-1} \cdot \mathrm{yr}^{-1}\right)$ or $<0.5 \%$ of the critical deposition load (CDL) of vegetation (Van Dobben et al., 2006) does not result in significant ecological effects. In Dutch legislation, it is assumed that as long as separate energy, industry or agricultural projects remain below the threshold of $0.05 \mathrm{Mol} \mathrm{N} \cdot \mathrm{ha}^{-1} \cdot \mathrm{yr}^{-1}$, the value of $\sim 70 \mathrm{Mol} \mathrm{N} \cdot \mathrm{ha}^{-1} . \mathrm{yr}^{-1}$ is not likely to be exceeded.

Since power plants emit both $\mathrm{NO}_{x}$ and $\mathrm{NH}_{4}$, we also calculated the eutrophication potential of power plants, based on Heijungs et al. (1992). For this we assumed $1 \mathrm{~kg} \mathrm{NO}=0.13 \mathrm{~kg} \mathrm{PO}_{4}$-eq. and $1 \mathrm{~kg} \mathrm{NH} 4=0.33 \mathrm{~kg} \mathrm{PO}_{4}$-eq. Moreover, eutrophication efficiency was calculated as $\mathrm{PO}_{4}$ eq. $\mathrm{MWh}^{-1} \cdot \mathrm{yr}^{-1}$. QGIS software (QGIS 2.6.1, 2016) was used to create a deposition map that shows 
the impact area of each power plant. The AERIUS GML output file was used as a vector layer in QGIS, and a map was created that shows the location of the emission source and nitrogen deposition relative to the Natura 2000 sites.

\subsection{Nature area impacts}

The impact area of an emission source was defined as the surface area of habitat types within Natura 2000 sites where nitrogen deposition exceeds $0.05 \mathrm{Mol} \mathrm{N} \cdot \mathrm{ha}^{-1} . \mathrm{yr}^{-1}$. However, cumulative impacts need to be considered, as multiple overlapping projects may result in exceedance of nitrogen deposition limits in a certain area (Galloway et al., 2008). Therefore, we took into account the 'background deposition' (BD), including nitrogen emissions from all possible existing sources, deposited on the nature area under investigation. For each Natura 2000 site, the spatial distribution maps of background deposition is available (Ministry of Agriculture, Nature and Food Security, 2018) and BD can thus be spatially calculated for each habitat type. A table of emission sources was created that also contains the BD per habitat type for each Natura 2000 site.

Generic data on Natura 2000 sites and habitat types were integrated in a database, providing the basis for all case-specific calculations. Nitrogen emissions of power plants also affect nitrogensensitive nature areas in adjacent countries (i.e. Belgium and Germany). For these countries, not all data were readily available and some assumptions had to be made. Three adjustments were made to the protocol in Belgium and Germany. First, the deposition value for the Natura 2000 site was assumed to be the same for all habitat types present within the site. The occurring habitat types in foreign sites were extracted from the European Environmental Agency (2016). Second, for Germany, BD was determined from an interactive map (Bundesamt für Umwelt BAFU, 2009) based on the centre UTM coordinates of each Natura 2000 site and given in $\mathrm{kg} \mathrm{N} \mathrm{ha}^{-1} \cdot \mathrm{yr}^{-1}$. This value was then assumed to be equal for all habitat types present within the Natura 2000 site. For Belgium, the less accurate EMEP model was used, which calculates long-range transboundary air pollution data at a $50 \times 50 \mathrm{~km}$ grid (Convention on Long-range Transboundary Air Pollution, 2014). The total oxidized and reduced $\mathrm{N}$ depositions were extracted for 2014 in $\mathrm{mg} \mathrm{N} \cdot \mathrm{m}^{-2} \cdot \mathrm{yr}^{-1}$, both as a semicolonseparated file and a graphic map, and converted to Mol. The Belgian BD was known per grid cell, for longitude and latitude coordinates. For each Natura 2000 site, the BD was interpolated based on these coordinates. Third, the share of the deposition by Dutch sectors in the total BD was 
determined for each Natura 2000 site, and the average energy sector deposition in the Netherlands, Belgium and Germany was calculated to be $55.43 \%$ of the total BD (Sauter et al., 2011).

The CDL of habitat types was assessed, using data from Van Dobben et al. (2006) and Wamelink et al. (2011). All CDL data were collected in a separate database for further processing. Next, the surface areas of habitat types within the Natura 2000 sites were assessed, taking into account their relative spatial coverage (Ministry of Agriculture, Nature and Food Security, 2018).

The database comprised 175 different habitat types. This large number makes a meaningful presentation of results difficult, which is why different habitat types were merged into broader 'vegetation types' according to vegetation structure and CDL. A total of 16 vegetation types were defined (see supplementary material and Table S1).

To calculate the share of nitrogen emissions that power plants are responsible for, the assumption was made that this share is calculated as the nitrogen emissions of power plant activity divided by the total explained nitrogen deposition per Natura 2000 site from emissions caused by all Dutch sectors. This approach was chosen as a significant part of the total nitrogen deposition cannot be attributed to single parties, due to natural sources and due to emissions from abroad. The responsible share of a single power plant was calculated as:

Responsible share $(\%)=\frac{\text { Nitrogen deposition by power plant }\left(\mathrm{mol} \mathrm{N}_{\mathrm{N}} \mathrm{ha}^{-1} \cdot \mathrm{yr}^{-1}\right)}{\text { Nitrogen deposition all sectors }\left(\mathrm{mol} \mathrm{N} \cdot \mathrm{ha}^{-1} \cdot \mathrm{yr}^{-1}\right)}$

The magnitude of impact is determined by the extent to which background deposition exceeds CDL. For example, if the $\mathrm{BD}$ is 1.5 times higher than the $\mathrm{CDL}$, the local boundary is in fact $50 \%$, indicating that the compensation area needs to be adjusted. Therefore, the relative exceedance of the CDL was determined for each habitat type (i) to define a compensation factor:

Compensation factor $\mathrm{i}_{\mathrm{i}}=\frac{\mathrm{BD}_{i}\left(\mathrm{~mol} \mathrm{~N}_{\mathrm{ha}} \mathrm{ha}^{-1} \cdot \mathrm{yr}^{-1}\right)}{\mathrm{CDL}_{i}\left(\mathrm{~mol} \mathrm{~N} \cdot \mathrm{ha}^{-1} \cdot \mathrm{yr}^{-1}\right)}$

Where $\mathrm{i}=$ habitat type in Natura 2000 sites, $\mathrm{BD}=$ background deposition level, $\mathrm{CDL}=$ critical deposition load

To estimate biodiversity effects, we first assumed that if the background deposition at a specific Natura 2000 location is lower than the CDL of a habitat type, this habitat will not be impacted by the power plant. Conversely, if $\mathrm{BD} \geq \mathrm{CDL}$, it is possible that a habitat type will be negatively 
impacted. To arrive at a value for biodiversity parameters, the impacted areas, the impacted Natura 2000 sites, and the impacted habitat types within the Natura 2000 sites were analysed using filter options in the output table, and they were aggregated to summed areas of impact for each power plant, aggregated for each habitat type and vegetation type.

The area to be compensated is calculated as a function of nitrogen deposition per habitat type, the compensation factor and the affected surface area. The final value represents the sum of all spatially explicit small contributions to the degradation of the Natura 2000 sites where nitrogen deposition by the power plant exceeds $0.05 \mathrm{Mol} \mathrm{N}_{\mathrm{ha}} \mathrm{har}^{-1} \cdot \mathrm{yr}^{-1}$, and BD > CDL:

Compensation area $(\mathrm{ha})=\sum_{\mathrm{i}=\mathrm{i}}^{\mathrm{n}}\left(\right.$ Responsible share $_{\mathrm{i}}$. Compensation factor $\mathrm{r}_{\mathrm{i}}$. Affected surface area $\left.\mathrm{a}_{\mathrm{i}}\right)$

Where $\mathrm{i}=$ habitat type in Natura 2000 sites

In addition to affected area by power plants, the relative affected area was calculated as affected area per unit eutrophication potential in $\mathrm{Ha} \cdot \mathrm{PO}_{4}$-eq. ${ }^{-1}$.

\subsection{Biodiversity costs}

Impacts could be avoided by measures of nitrogen emission reductions. However, these are already frequently deployed in the electricity-supply sector by applying De- $\mathrm{NO}_{x}$ filters or choosing a location that is less sensitive to nitrogen. Therefore, it may be assumed that no substantial additional efficiency measures will occur (IPCC, 2007), which is why compensation and offsets will be calculated.

To estimate the cost of biodiversity impacts, we applied the condition $\mathrm{x}$ area assumption (Bull et al., 2013), in which any impacted vegetation needs to be compensated by a similar vegetation or habitat type. Cost of compensation may vary widely, depending on the cost method applied. We used three types of cost compensation estimates:

1) Restoration costs, in which we assumed that impacted vegetation can be restored by applying specific nature management, such as sod cutting and liming. Costs were derived from various sources (see supplementary material) and calculated as:

Restoration costs $(€)=\sum_{\mathrm{i}=\mathrm{i}}^{\mathrm{n}}$ Compensation area (ha) $)_{\mathrm{i}}$. Unit restoration costs $\left(€ \mathrm{ha}^{-1}\right)_{\mathrm{i}}$ 
2) 'Insetting' costs, in which degraded vegetation is completely converted to the original state; this goes beyond usual restoration. For this, we assumed conversion takes place within nature areas and includes various types of intervention, from removing the top soil to building water works and planting trees. We used unit cost prices of such measures (Sijtsma et al., 2017), which were then further detailed for habitat types (see supplementary material). Insetting costs were calculated as:

Insetting costs $(€)=\sum_{\mathrm{i}=\mathrm{i}}^{\mathrm{n}}$ Compensation area (ha) $)_{\mathrm{i}}$. Unit conversion costs $\left(€ \mathrm{ha}^{-1}\right)_{\mathrm{i}}$

3) 'Offsetting' costs include the above conversion measures but instead take place outside Natura 2000 areas, for example the creation of new nature on former agricultural land. Hence, offsetting also includes the cost of land purchase. We used the Dutch agricultural land prices database at provincial level (see supplementary material and Table S2). Offsetting costs were calculated as:

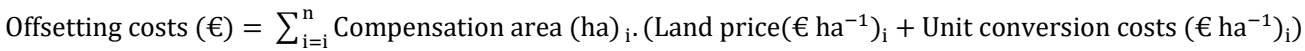

For eq. 4.1-4.3: $\mathrm{i}=$ habitat type within Natura 2000 sites.

\subsection{Sensitivity analysis}

A sensitivity analysis was performed on the input parameters that may influence the outcome of calculations. For each input parameter, variations of $+10 \%$ or $-10 \%$ were applied, while keeping all other parameters constant. The sensitivity analysis was carried out for BD, deposition by single power plants, CDL of habitat types, and costs of restoration, conversion and land purchase. The effect of a $10 \%$ increase or decrease of each parameter was evaluated on these cost estimates.

\subsection{Data handling and statistical analysis}

For all statistical analyses, the data output files were further processed. Per power plant, the output files included names and codes of affected Natura 2000 sites, habitat type codes, and the various calculated parameters for each habitat type within Natura 2000 sites. The number of affected Natura 2000 sites differed among the power plants: for Plants 1 to 4 these were 108, 58, 107 and 1, respectively. Since each Natura 2000 site may include multiple habitat types and the affected areas for each habitat type were summed, the full dataset included 571 (Plant 1), 262 (Plant 2), 591 (Plant 3) and 5 (Plant 4) observations. 
To calculate and test the distance effects from power plants, a distance map in QGIS was made using the spatial locations of a power plant and the centre of each affected Natura 2000 site. This map was then converted into an Excel table for further processing.

The relationship between power plant distance, as 1 /distance, and nitrogen deposition on habitat types in Natura 2000 sites was tested by linear regression, while Pearson Product-Moment correlations were carried out between power plant distance and the responsible share of power plants, exceedance of CDL of habitat types and affected surface areas of habitat types. All statistical tests were carried out using IBM SPSS, version 25 (IBM, 2017).

\section{Results}

The power plant characteristics, including emission loads, the affected Natura 2000 areas and the calculated compensation areas are presented in Table 1. The amount of nitrogen deposition on Dutch Natura 2000 areas showed a significant and inverse relationship with power plant distance (Figure 3, Table 2). This regression was not calculated for affected Natura 2000 areas in Belgium and Germany, while Plant 4 only affected one adjacent Natura 2000 site at $<3 \mathrm{~km}$ distance. The responsible share of total deposition was significantly negatively but non-linearly correlated with power plant distance (Table 3), indicating that this share decreases with emission distance. Only for Plant 1 was the affected surface area of habitat types significantly and negatively correlated to distance (Table 3). For plant 3, CDL exceedance was significantly positively correlated to distance, while this was not the case for Plants 1 and 2.

\subsection{Affected surface area by vegetation type}

A positive relationship was found between the eutrophication potential of single power plants and affected area (Table 1), but an increase in the eutrophication potential of a power plant does not lead to an equal increase in the total affected area (see relative affected area, Table 1). The regressions between nitrogen deposition and affected surface areas were only significant for Plants 1 and 2 (see Table 4).

The distribution of affected habitat types differed among the power plants. Grouping Natura 2000 habitat types into generic vegetation types (see supplementary material) and averaging the affected area per vegetation type, showed that dunes, raised bogs, heaths and forests had 
relatively large affected areas at any given deposition level (Figure 4). This cannot be fully explained by their higher CDL, since fens, species-rich grasslands and raised bogs have equal or even higher CDL levels (see supplementary material).

\subsection{Affected Natura 2000 areas abroad}

The emissions deposited in Germany and Belgium were calculated separately (see Methods). The affected surface areas by power plants are listed in Table 5, grouped by vegetation type. The total area affected by nitrogen deposition for Plants 1-4 was 1,393 ha, 714 ha, 1,292 ha and < 1 ha, respectively. Furthermore, the transboundary deposition effects were largest for forest vegetation.

\subsection{Compensation area and costs}

The cumulative affected and compensation areas of Plants 1-3 showed that the compensation area increased linearly with the affected area for Plant 2 (Figure 5). This was not the case for Plants 1 and 3. For Plant 1, the cumulative compensation area increased more than linearly at approximately 33,000 hectares of affected area. For Plant 3, the cumulative compensation area saturated at approximately 33,000 ha of affected area.

Cost curves for the cumulative nitrogen deposition of Plants 1-3 and separated by vegetation types differed between the three cost estimates (Figure 6). For restoration costs, dunes showed a steep increase in cumulative costs, with cumulative power plant deposition loads leading to the highest restoration costs. The largest summed deposition loads were found for heath and forests, leading to the second largest summed restoration costs for heathland, but relatively lower costs for forests. For 'insetting' and offsetting estimates, dunes showed low cumulative costs, as no conversion costs could be established for the most common habitat types that constitute dune vegetation (see supplementary material). For both insetting and offsetting, the highest cumulative costs were found for heath, forest and raised bogs. Compared to insetting costs, the cumulative offsetting costs of forests approached the curve of heath.

Restoration, insetting (conversion costs only) and offsetting (conversion and land purchase costs) provided a range of cost estimates. Per unit, area restoration costs were on average almost one third of the average conversion costs ( $€ 13,254$. ha $^{-1}$ versus $€ 31,223$. ha-1 $)$, but this was not the case for some specific habitat or vegetation types, such as dune habitat types H2110-H2130 (see 
supplementary material). While total restoration costs levelled off with the eutrophication potential of power plants, both 'insetting' and offsetting costs increased with the eutrophication potential (Figure 7). The cost of dunes added most to the total restoration costs of Plants 1 and 3, while heath and forest added most to the insetting and offsetting costs. Although land prices may differ among provinces by up to $50 \%$ (supplementary material), the cost curve patterns across vegetation types did not differ between insetting and offsetting.

Per unit of eutrophication potential, restoration had the lowest average costs of $3.74 € \cdot \mathrm{PO}_{4}$-eq-1. $\mathrm{yr}^{-}$ ${ }^{1}$ (Table 6). The highest average costs were $30.89 € \cdot \mathrm{PO}_{4}-\mathrm{eq}^{-1} \cdot \mathrm{yr}^{-1}$ (offsetting). Per unit of energy produced, restoration had the lowest average costs of $0.11 € . \mathrm{MWh}^{-1} \cdot \mathrm{yr}^{-1}$ while offsetting had the highest average costs: $1.13 € . \mathrm{MWh}^{-1} \cdot \mathrm{yr}^{-1}$. However, the range of biodiversity footprint cost estimates is large; the highest cost range per unit of energy produced was found for restoration costs, while 'insetting' and offsetting costs showed the largest range in costs per unit of eutrophication potential.

\subsection{Sensitivity analysis}

Changes of $10 \%$ in input parameters led to an equal change in calculated restoration costs, construction costs, land purchase and deposition levels by power plants (Figure 8). This $10 \%$ change in CDL led to a slightly larger change in output costs $(-9.09 \%$ and $11.11 \%)$. In addition, a $10 \%$ lower CDL led to $11.1 \%$ higher costs and vice versa (Figure 8 ). The calculated costs were most sensitive to changes in BD. A $10 \%$ change led to $15.7 \%$ lower or $31.3 \%$ higher costs. The disproportionally higher costs by an increase in 10\% BD were due to a disproportionally larger amount of affected nature area at high BD.

\section{Discussion}

In approximately $70 \%$ of protected Natura 2000 areas in the Netherlands, the nitrogen deposition levels are well beyond the critical loads of habitat types (Wamelink et al., 2013). Desiccation of nature areas enhances the detrimental effects of nitrogen deposition and occurs in $91 \%$ of Dutch Natura 2000 areas (Wamelink et al., 2013). All types of vegetation are susceptible to excessive nitrogen, but heath, raised bogs and species-rich grasslands are particularly sensitive to nitrogen surplus, leading to a strong decline in plant species richness (Bobbink et al., 2010). 
While agriculture, and particularly animal husbandry, is by far the major cause of nitrogen (ammonia) emissions in the Netherlands (Erisman et al., 2007; Kros et al., 2013), we showed that nitrogen emissions from single power plants also add substantially to this environmental pressure. According to our calculations, single power plants that annually emit between 22,720 and 365,138 kg NOx affected between 7,712 and 53,695 ha of nature area in protected Natura 2000 sites in the Netherlands. Nitrogen emitted by power plants are deposited and diluted over large distances, making biodiversity impact assessments very difficult (Curran et al., 2011; Huijbregts et al., 2001; Vijayaraghavan et al., 2010). Curran et al. (2011) reviewed the use of indicators and approaches to model biodiversity loss in Life Cycle Assessment. Although some models and approaches take eutrophication into account, current approaches largely ignore the spatial distribution of biodiversity (Curran et al., 2011). In previous attempts, such as the RAINS-LCA model (Huijbregts et al., 2001), nitrogen emissions and acidifying components were spatially calculated per economic sector, but not per single point sources.

In our framework, not only the spatial distributions of deposition and vegetation types, but also the location of emission sources was explicitly taken into account. For this we used the OPS model (Sauter et al., 2011; Wichink Kruit et al., 2017), which is incorporated in the publicly available AERIUS web-tool. However, AERIUS also sets the limitation that only depositions above the threshold of $0.05 \mathrm{Mol} \mathrm{N} \cdot \mathrm{ha}^{-1} \cdot \mathrm{yr}^{-1}$ can be assessed. This suggests that we may have underestimated the biodiversity footprint of power plants. Although we included only four power plants in our analysis, the results indicate that the affected nature area levelled off with the eutrophication potential of emission sources, while the compensation area linearly increased with the eutrophication potential. Since the compensation area largely depends on the current state of nature areas, and hence the level of background nitrogen deposition, it is not possible to draw general conclusions about the relationship between the eutrophication potential of a single power plant and the nature compensation area. In addition, the sensitivity analysis showed that the contribution of other economic activities to nitrogen deposition must be taken into account, since the level of background deposition will affect the compensation area of single power plants. Strong emission reduction measures, which may be taken by for example the agricultural sector (Van der Heyden et al., 2016), can result in a strong reduction of this background deposition. The affected nature areas by single power plants will not change, but compensation areas and associated costs may be reduced considerably. 
Compensation costs of single power plants varied strongly between the cost method applied and the location of power plants. Cost estimates ranged between $0.06 € . \mathrm{MWh}^{-1}$ and $1.65 € . \mathrm{MWh}^{-1}$ and corresponded to between 2.2 and $36.94 € . \mathrm{PO}_{4}$-eq. ${ }^{-1}$ of eutrophication costs. Various researchers have estimated the costs of $\mathrm{NO}_{x}$ emissions, but these are mostly based on health effects. For example, Wang et al. (2015) and Klaassen and Riahi (2007) calculated the external costs of coalfired power plants of 4500 US\$.ton ${ }^{-1}$ and $7000 € \cdot$ ton $^{-1} \mathrm{NO}_{x}$. These figures roughly correspond to 1.38 to $2.4 € . \mathrm{MWh}^{-1}$. Štreimikienè (2017) estimated costs of nitrogen emissions of $3266 €$.ton ${ }^{-1}$ $\left(\mathrm{NH}_{3}\right)$ and $903 € \cdot$ ton $^{-1}\left(\mathrm{NO}_{x}\right)$. These estimates were based on air pollution taxes but not on biodiversity restoration costs.

Estimating an economic value of biodiversity loss has been shown to be notoriously difficult (Hahn et al., 2015; Maron et al., 2012) and to be based on a variety of methods (Nunes and van den Bergh, 2001). We took the approach to estimate the economic costs of an environmental pressure (i.e. nitrogen emissions) on biodiversity. We adopted the so-called standard cost approach (Sijtsma et al., 2017) on restoration and land conversion, using the assumption of Bull et al. (2013) that compensation must include the same area and type of vegetation. This standard cost approach has been applied in the Netherlands in nature policy scenarios (Sijtsma et al., 2017) and in road development projects (Cuperus et al., 2001). It includes various financial data of measures that have been taken in different contexts. Yet, in reality, some nature areas may need little modification, leading to an overshoot of cost estimates, while other more severely degraded areas may have higher restoration costs than assumed by the cost approach. To gain some insight into the range of such cost estimates, we used three different assumptions: restoration measures (lowest estimate), a full conversion of vegetation types within nature areas to the original state ('insetting' costs), and conversion of land to nature that takes place on adjacent, mostly agricultural, land (offsetting, highest estimate). These different cost estimates not only resulted in expected differences in total compensation costs but also showed that the distribution of costs across vegetation types differed by the cost method applied.

Corporations that apply the concept of a One Planet Approach and strive to operate within planetary boundaries should embrace no-net-loss of biodiversity (Brownlie et al., 2013; Clift et al., 2017). Rather than compensating negative impacts, such impacts should be avoided by incorporating low- or zero-emission technologies. Biomass combustion leads to overall lower nitrogen emissions (Venturini et al., 2015), and one of our four assessed power plants used 
renewable biomass as energy feedstock. Indeed, this plant had an $80 \%$ lower eutrophication potential per unit of electricity produced than the natural gas-fired plants 1 and 2, but only a $25 \%$ lower eutrophication potential than the natural gas-fired Plant 3. Due to the relatively low annual energy production and the more favourable plant location, no compensation area was estimated for this bioenergy power plant. However, the affected nature area per unit of eutrophication potential was comparable to the other, gas-fired, power plants in our study. This indicates that renewables, such as biomass, can reduce but not avoid the biodiversity footprint of energy production.

Sustainability reporting has become increasingly important to companies, but the current focus on reducing carbon emissions may come at the expense of other negative impacts such as biodiversity (Milne and Gray, 2013). Estimates of biodiversity loss due to business activities have to date rarely been incorporated in environmental reporting (Haffar and Searcy, 2018; Jones and Solomon, 2013). We have shown that it is possible to determine contextual biodiversity impacts and the associated costs of a company's operational activities, indicating that this can be used in environmental reporting such as the Global Reporting Initiative (Alazzani and Wan-hussin, 2013; Haffar and Searcy, 2018). To do so, impacts need to be calculated for each individual point source, since its location and type of affected vegetation may strongly vary.

As Milne and Gray (2013) argued, environmental reporting alone will not make corporations more sustainable. Moreover, current sustainability reporting is usually confined to generic indicators and management narratives that lack specific context (Skouloudis et al., 2019). Therefore, reporting all too often reinforces business reputation but does not necessarily lead to protecting ecological systems as it focuses on the costs of risk avoidance and management. Furthermore, the various types of measures that underlie cost estimates assume that the current unfavourable state of nature areas can be reverted by compensation. Yet, ecological processes may be irreversibly changed by such economic pressures (Quétier and Lavorel, 2011), leading to very limited longterm positive biodiversity effects of restoration and compensation activities. Therefore, calculating the biodiversity footprints of economic activities, such as energy production, should trigger the uptake of more biodiversity-friendly technologies rather than compensating these impacts (Ali et al., 2018). 


\section{Acknowledgements}

We would like to thank Gerben Meijer of Eneco for supervising Floor Osseweijer during her internship and Dr Pita Verweij for her critical comments on an earlier version of the manuscript. We would also like to acknowledge all plant managers, directors and environmental experts for their cooperation during field visits and data provisioning. 


\section{References}

Alazzani, A., Wan-hussin, W.N., 2013. Global Reporting Initiative 's environmental reporting : A study of oil and gas companies. Ecol. Indic. 32, 19-24.

https://doi.org/10.1016/j.ecolind.2013.02.019

Ali, M., Kennedy, C.M., Kiesecker, J., Geng, Y., 2018. Integrating biodiversity offsets within Circular Economy policy in China. J. Clean. Prod. 185, 32-43. https://doi.org/10.1016/j.jclepro.2018.03.027

Apostolopoulou, E., 2016. Biodiversity offsetting in England: Governance rescaling, socio-spatial injustices, and the neoliberalization of nature. Web Ecol. 16, 67-71. https://doi.org/10.5194/we-16-67-2016

Bidstrup, M., Pizzol, M., Schmidt, J.H., 2015. Life Cycle Assessment in spatial planning - A procedure for addressing systemic impacts. J. Clean. Prod. 91, 136-144. https://doi.org/10.1016/j.jclepro.2014.12.027

Bobbink, R., Hicks, K., Galloway, J., Spranger, T., Alkemade, R., Ashmore, M., Bustamante, S., Cinderby, S., Davidson, E., Dentener, F., Emmett, B., Erisman, J., Fenn, M., Gilliam, F., Nordin, A., Pardo, L., de Vries, W., 2010. Global assessment of nitrogen deposition effects on terrestrial plant diversity: Asynthesis. Ecol. Appl. 20, 30-59. https://doi.org/10.1890/081140.1

Brooks, T.M., Akçakaya, H.R., Burgess, N.D., Butchart, S.H.M., Hilton-Taylor, C., Hoffmann, M., J uffe-Bignoli, D., Kingston, N., MacSharry, B., Parr, M., Perianin, L., Regan, E.C., Rodrigues, A.S.L., Rondinini, C., Shennan-Farpon, Y., Young, B.E., 2016. Analysing biodiversity and conservation knowledge products to support regional environmental assessments. Sci. data 3, 160007. https://doi.org/10.1038/sdata.2016.7

Brown, H.S., de Jong, M., Levy, D.L., 2009. Building institutions based on information disclosure: lessons from GRI's sustainability reporting. J. Clean. Prod. 17, 571-580. https://doi.org/10.1016/j.jclepro.2008.12.009

Brownlie, S., King, N., Treweek, J., 2013. Biodiversity tradeoffs and offsets in impact assessment and decision making: Can we stop the loss? Impact Assess. Proj. Apprais. 31, 24-33. https://doi.org/10.1080/14615517.2012.736763 
Bull, J.W., Suttle, K.B., Singh, N.J., Milner-Gulland, E.J., Gordon, A., Singh, N.J., Milner-Gulland, E.J., 2013. Biodiversity offsets in theory and practice. Oryx 47, 369-380. https://doi.org/10.1017/S003060531200172X

Bundesamt für Umwelt BAFU, 2009. Hintergrundbelastungsdaten Stickstoff [WWW Document]. URL http://gis.uba.de/website/depol/ (accessed 6.20.05).

Carnell, E.J., Misselbrook, T.H., Dore, A.J., Sutton, M.A., Dragosits, U., 2017. A methodology to link national and local information for spatial targeting of ammonia mitigation efforts. Atmos. Environ. 164, 195-204. https://doi.org/10.1016/j.atmosenv.2017.05.051

Clift, R., Sim, S., King, H., Chenoweth, J.L., Christie, I., Clavreul, J., Mueller, C., Posthuma, L., Boulay, A.M., Chaplin-Kramer, R., Chatterton, J., DeClerck, F., Druckman, A., France, C., Franco, A., Gerten, D., Goedkoop, M., Hauschild, M.Z., Huijbregts, M.A.J., Koellner, T., Lambin, E.F., Lee, J., Mair, S., Marshall, S., McLachlan, M.S., Milà i Canals, L., Mitchell, C., Price, E., Rockström, J., Suckling, J., Murphy, R., 2017. The challenges of applying planetary boundaries as a basis for strategic decision-making in companies with global supply chains. Sustain. 9, 1-23. https://doi.org/10.3390/su9020279

Commission of the European Communities, 2009. Communication From the Commission to the Council, the European Parliament, the European Economic and Social Committee, and the Committee of the Regions: A Mid-Term Assessment of Implementing the EC Biodiversity Action Plan. J. Int. Wildl. Law Policy 12, 108-120. https://doi.org/10.1080/13880290902938435

Convention on Long-range Transboundary Air Pollution, 2014. EMEP/MSC-W [WWW Document]. URL http://webdab.emep.int/Unified_Model_Results/ (accessed 6.20.05).

Cuperus, R., Bakermans, M.M.G.J., Udo De Haes, H.A., Canters, K.J., 2001. Ecological compensation in Dutch highway planning. Environ. Manage. 27, 75-89.

Curran, M., de Baan, L., De Schryver, A., Van Zelm, R., Hellweg, S., Koellner, T., Sonnemann, G., Huijbregts, M., 2011. Toward meaningful end points of biodiversity. Environ. Sci. Technol. 45, 70- 79 .

De Heer, M., Roozen, F., Maas, R., 2017. The Integrated Approach to Nitrogen in the Netherlands: A preliminary review from a societal, scientific, juridical and practical perspective. J. Nat. 
Conserv. 35, 101-111. https://doi.org/10.1016/j.jnc.2016.11.006

Dise, N.B., Ashmore, M., Belyazid, S., Bleeker, A., Bobbink, R., Vries, W. De, Erisman, J.W., Spranger, T., Stevens, C.J., Berg, L. Van Den, 2011. Nitrogen as a threat to European terrestrial biodiversity, in: Sutton, M.A., Howard, C.M., Erisman, J.W., Billen, G., Bleeker, A., Grennfelt, P., van Grinsven, H., Grizetti, B. (Eds.), The European Nitrogen Assessment. Cambridge University Press, Cambridge, New York, Melbourne, Madrid, Cape Town, Singapore, São Paulo, Delhi, Tokyo, Mexico City, pp. 463-494.

Eidelwein, F., Collatto, D.C., Rodrigues, L.H., Lacerda, D.P., Piran, F.S., 2018. Internalization of environmental externalities: Development of a method for elaborating the statement of economic and environmental results. J. Clean. Prod. 170, 1316-1327.

https://doi.org/10.1016/j.jclepro.2017.09.208

Eksi, G., Karaosmanoglu, F., 2018. Life cycle assessment of combined bioheat and biopower production: An eco-design approach. J. Clean. Prod. 197, 264-279. https://doi.org/10.1016/j.jclepro.2018.06.151

Erisman, J.W., Bleeker, A., Galloway, J., Sutton, M.S., 2007. Reduced nitrogen in ecology and the environment. Environ. Pollut. 150, 140-149. https://doi.org/10.1016/j.envpol.2007.06.033

European Environmental Agency, 2016. Natura 2000 data - the European network of protected sites [WWW Document]. URL http://www.eea.europa.eu/data-and-maps/data/natura-7 (accessed 6.20.03).

Galloway, J.D., Townsend, A.R., Erisman, J.W., Bekunda, M., Cai, Z., Freney, J.R., Martinelli, L. a, Seitzinger, S.P., Sutton, M. a, 2008. Transformation of the Nitrogen Cycle. Science 320, 889-892. https://doi.org/10.1126/science.1136674

Gardner, T.A., Von Hase, A., Brownlie, S., Ekstrom, J.M.M., Pilgrim, J.D., Savy, C.E., Stephens, R.T.T., Treweek, J., Ussher, G.T., Ward, G., Ten Kate, K., 2013. Biodiversity Offsets and the Challenge of Achieving No Net Loss. Conserv. Biol. 27, 1254-1264. https://doi.org/10.1111/cobi.12118

Haffar, M., Searcy, C., 2018. The use of context-based environmental indicators in corporate reporting. J. Clean. Prod. 192, 496-513. https://doi.org/10.1016/j.jclepro.2018.04.202

Hahn, T., McDermott, C., Ituarte-Lima, C., Schultz, M., Green, T., Tuvendal, M., 2015. Purposes 
and degrees of commodification: Economic instruments for biodiversity and ecosystem services need not rely on markets or monetary valuation. Ecosyst. Serv. 16, 74-82. https://doi.org/10.1016/j.ecoser.2015.10.012

Heijungs, R., Guinée, J.B., Huppes, G., Lamkreijer, R.M., Udo de Haes, H., Wegener Sleeswijk, A., Ansems, A.M.M., Eggels, P.G., van Duin, R., de Goede, H.P., 1992. Environmental Life Cycle Assessment of Products.

Huijbregts, M.A.J., Schopp, W., Verkuijlen, E., Heijungs, R., Reijnders, L., 2001. Spatially Explicit Characterization of Acidifying and Eutrophying Air Pollution in Life-Cycle Assessment. J . Ind. Ecol. 4, 75-92.

IBM, 2017. SPSS Statistics, version 25, Release 25.0.0.1.

IPCC, 2007. Climate Change 2007: Working Group III: Mitigation of Climate Change. Cambridge, New York, Melbourne, Madrid, Cape Town, Singapore, São Paolo, Delhi.

Jones, M.J., Solomon, J.F., 2013. Problematising accounting for biodiversity. Accounting, Audit. Account. J. 25, 668-687. https://doi.org/10.1108/AAAJ-03-2013-1255

Jose, A., Lee, S.M., 2007. Environmental reporting of global corporations: A content analysis based on Website disclosures. J. Bus. Ethics 72, 307-321. https://doi.org/10.1007/s10551-0069172-8

Klaassen, G., Riahi, K., 2007. Internalizing externalities of electricity generation: An analysis with MESSAGE-MACRO. Energy Policy 35, 815-827. https://doi.org/10.1016/j.enpol.2006.03.007

Klöpffer, W., Curran, M.A., 2016. LCA Compendium - The Complete World of Life Cycle Assessment: Background and Future Prospects in Life Cycle Assessment. Springer, Dordecht. https://doi.org/10.1007/978-94-017-8697-3

Kros, J., Gies, T.J.A., Voogd, J.C.H., De Vries, W., 2013. Efficiency of agricultural measures to reduce nitrogen deposition in Natura 2000 sites. Environ. Sci. Policy 32, 68-79. https://doi.org/10.1016/j.envsci.2012.09.005

Kuylenstierna, J.C.I., Hicks, W.K., Cinderby, S., Cambridge, H., 1998. Critical loads for nitrogen deposition and their exceedance at European scale. Environ. Pollut. 102, 591-598. https://doi.org/10.1016/S0269-7491(98)80087-0 
Maron, M., Hobbs, R.J., Moilanen, A., Matthews, J.W., Christie, K., Gardner, T.A., Keith, D.A., Lindenmayer, D.B., McAlpine, C.A., 2012. Faustian bargains? Restoration realities in the context of biodiversity offset policies. Biol. Conserv. 155, 141-148. https://doi.org/10.1016/j.biocon.2012.06.003

Marques, A., Verones, F., Kok, M.T., Huijbregts, M.A., Pereira, H.M., 2017. How to quantify biodiversity footprints of consumption? A review of multi-regional input-output analysis and life cycle assessment. Curr. Opin. Environ. Sustain. 29, 75-81. https://doi.org/10.1016/j.cosust.2018.01.005

Milne, M.J., Gray, R., 2013. W (h) ither Ecology? The Triple Bottom Line, the Global Reporting Initiative, and Corporate Sustainability Reporting. J. Bus. Ethics 118, 13-29. https://doi.org/10.1007/s10551-012-1543-8

Ministry of Agriculture, Nature and Food Security, 2018. Profiles habitat types and species [WWW Document]. https: //www.synbiosys. alterra.nl/natura2000/gebiedendatabase. aspx?subj=profielen.

Moslehi, S., Reddy, T.A., 2019. An LCA methodology to assess location-specific environmental externalities of integrated energy systems. Sustain. Cities Soc. 46, 101425. https: //doi.org/10.1016/j.scs.2019.101425

Nunes, P.A.L.D., van den Bergh, J.C.J.M., 2001. Economic valuation of biodiversity: sense or nonsense? Ecol. Econ. 39, 20. https://doi.org/http://dx.doi.org/10.1016/S09218009(01)00233-6

Pilgrim, J.D., Ekstrom, J.M.M., 2014. Technical conditions for positive outcomes from biodiversity offsets. An input paper for the IUCN Technical Study Group on Biodiversity Offsets. IUCN, Gland, Switzerland.

Quétier, F., Lavorel, S., 2011. Assessing ecological equivalence in biodiversity offset schemes: Key issues and solutions. Biol. Conserv. 144, 2991-2999. https: //doi.org/ 10.1016/j.biocon. 2011.09.002

Rockström, J., Steffen, W., Noone, K., Persson, Å., Stuart Chapin, III, F., Lambin, E.F., Lenton, T.M., Scheffer, M., Folke, C., Schellnhuber, H.J., Nykvist, B., de Wit, C.A., Hughes, T., van der Leeuw, S., Rodhe, H., Sörlin, S., Snyder, P.K., Costanza, R., Svedin, U., Falkenmark, M., 
Karlberg, L., Corell, R.W., Fabry, V.J ., Hansen, J., Walker, B., Liverman, D., Richardson, K., Crutzen, P., Foley, J.A., 2009. A safe operating space for humanity. Nature 461, 472-475.

Rosa, F.S. Da, Ensslin, S.R., Ensslin, L., Lunkes, R.J., 2012. Environmental disclosure management: a constructivist case. Manag. Decis. 50, 1117-1136. https://doi.org/10.1108/00251741211238364

Sabag Muñoz, O., Gladek, E., 2017. One Planet Approaches. Methodology mapping and pathways forward. Metabolic, WWF, FOEN, IUCN, (Switzerland, Netherlands, USA).

Sandin, G., Peters, G.M., Svanström, M., 2015. Using the planetary boundaries framework for setting impact-reduction targets in LCA contexts. Int. J. Life Cycle Assess. 20, 1684- 1700. https: //doi.org/10.1007/s11367-015-0984-6

Sauter, F., Swaluw, E. Van Der, Aben, J., Leeuw, F. De, Jaarsveld, H. Van, 2011. The OPS-model. Description of OPS 4.5.2. National Institute for Public Health and the Environment (RIVM), Bilthoven, the Netherlands.

Schoukens, H., Cliquet, A., 2016. Biodiversity offsetting and restoration under the European Union Habitats Directive. Ecol. Soc. 21.

Sijtsma, F.J., van der Bilt, W.G.M., van Hinsberg, A., de Knegt, B., van der Heide, M., Leneman, H., Verburg, R., 2017. Planning nature in urbanized countries. An analysis of monetary and non-monetary impacts of conservation policy scenarios in the Netherlands. Heliyon 3, e00280. https://doi.org/10.1016/j.heliyon.2017.e00280

Skouloudis, A., Malesios, C., Dimitrakopoulos, P.G., 2019. Corporate biodiversity accounting and reporting in mega-diverse countries: An examination of indicators disclosed in sustainability reports. Ecol. Indic. 98, 888-901. https://doi.org/10.1016/j.ecolind.2018.11.060

Steffen, W., Richardson, K., Rockström, J., Cornell, S.E., Fetzger, I., Bennett, E.M., Biggs, R., Carpenter, S.R., de Vries, W., de Wit, C.A., Folke, C., Gerten, D., Heinke, J., Mace, G.M., Persson, L.M., Ramanathan, V., Reyers, B., Sorlin, S., 2015. Planetary boundaries: Guiding human development on a changing planet. Science $347,1259855$. https: //doi.org/ 10.1126/science. 1259855

Stevens, C.J., 2016. How long do ecosystems take to recover from atmospheric nitrogen deposition? Biol. Conserv. 200, 160-167. https://doi.org/10.1016/j. biocon.2016.06.005 
Stevens, C.J., Gowing, D.J.G., Wotherspoon, K.A., Alard, D., Aarrestad, P.A., Bleeker, A., Bobbink, R., Diekmann, M., Dise, N.B., Dupre, C., Dorland, E., Gaudnik, C., Rotthier, S., Soons, M.B., Corcket, E., 2011. Addressing the Impact of Atmospheric Nitrogen Deposition on Western European Grasslands. Environ. Manage. 48, 885-894. https://doi.org/10.1007/s00267-011$9745-x$

Štreimikienè, D., 2017. Review of internalization of externalities and dynamics of atmospheric emissions in energy sector of Baltic States. Renew. Sustain. Energy Rev. 70, 1131-1141. https://doi.org/10.1016/j.rser.2016.12.017

Sutton, M.A., Mason, K.E., Sheppard, L.J., Sverdrup, H., Haeuber, I., Hicks, W.K., 2014. Nitrogen Deposition, Critical Loads and Biodiversity. Springer, Dordrecht, Heidelberg, New York, London.

Tan, J., Fu, J.S., Dentener, F., Sun, J., Emmons, L., Tilmes, S., Flemming, J., Takemura, T., Bian, H., Zhu, Q., Yang, C.E., Keating, T., 2018. Source contributions to sulfur and nitrogen deposition - An HTAP II multi-model study on hemispheric transport. Atmos. Chem. Phys. 18, 12223- 12240. https://doi.org/10.5194/acp-18-12223-2018

Thébaud, O., Boschetti, F., Jennings, S., Smith, A.D.M., Pascoe, S., 2015. Of sets of offsets: Cumulative impacts and strategies for compensatory restoration. Ecol. Modell. 312, 114-124. https://doi.org/10.1016/j.ecolmodel.2015.04.022

Van der Heyden, C., Brusselman, E., Volcke, E.I.P., Demeyer, P., 2016. Continuous measurements of ammonia, nitrous oxide and methane from air scrubbers at pig housing facilities. J. Environ. Manage. 181, 163-171. https://doi.org/10.1016/j.jenvman.2016.06.006

Van der Swaluw, E., de Vries, W., Sauter, F., Aben, J., Velders, G., van Pul, A., 2017. Highresolution modelling of air pollution and deposition over the Netherlands with plume, grid and hybrid modelling. Atmos. Environ. 155, 140-153. https://doi.org/10.1016/j.atmosenv.2017.02.009

Van Dobben, H.F., Van Hinsberg, A., Schouwenberg, E.P.A.G., Jansen, M., Mol-Dijkstra, J.P., Wieggers, H.J .J., Kros, J., De Vries, W., 2006. Simulation of critical loads for nitrogen for terrestrial plant communities in the Netherlands. Ecosystems 9, 32-45. https: //doi.org/10.1007/s10021-005-0052-3 
Venturini, E., Vassura, I., Zanetti, C., Pizzi, A., Toscano, G., Passarini, F., 2015. Evaluation of nonsteady state condition contribution to the total emissions of residential wood pellet stove. Energy 88, 650-657. https://doi.org/10.1016/j.energy.2015.05.105

Verones, F., Huijbregts, M.A.J., Chaudhary, A., De Baan, L., Koellner, T., Hellweg, S., 2015. Harmonizing the assessment of biodiversity effects from land and water use within LCA. Environ. Sci. Technol. 49, 3584-3592. https://doi.org/10.1021/es504995r

Vijayaraghavan, K., Seigneur, C., Bronson, R., Chen, S.Y., Karamchandani, P., Walters, J.T., Jansen, J.J., Brandmeyer, J.E., Knipping, E.M., 2010. A case study of the relative effects of power plant nitrogen oxides and sulfur dioxide emission reductions on atmospheric nitrogen deposition. J. Air Waste Manag. Assoc. 60, 287-293. https://doi.org/10.3155/10473289.60.3.287

Vivanco, M.G., Theobald, M.R., García-Gómez, H., Luis Garrido, J., Prank, M., Aas, W., Adani, M., Alyuz, U., Andersson, C., Bellasio, R., Bessagnet, B., Bianconi, R., Bieser, J., Brandt, J., Briganti, G., Cappelletti, A., Curci, G., Christensen, J.H., Colette, A., Couvidat, F., Cuvelier, C., D'Isidoro, M., Flemming, J., Fraser, A., Geels, C., Hansen, K.M., Hogrefe, C., Im, U., J orba, O., Kitwiroon, N., Manders, A., Mircea, M., Otero, N., Pay, M.T., Pozzoli, L., Solazzo, E., Tsyro, S., Unal, A., Wind, P., Galmarini, S., 2018. Modeled deposition of nitrogen and sulfur in Europe estimated by 14 air quality model systems: Evaluation, effects of changes in emissions and implications for habitat protection. Atmos. Chem. Phys. 18, 10199-10218. https://doi.org/10.5194/acp-18-10199-2018

Wamelink, G.W.W., de Knegt, B., Pouwels, R., Schuiling, C., Wegman, R.M.A., Schmidt, A.M., van Dobben, H.F., Sanders, M.E., 2013. Considerable environmental bottlenecks for species listed in the Habitats and Birds Directives in the Netherlands. Biol. Conserv. 165, 43-53. https://doi.org/10.1016/j. biocon.2013.05.012

Wamelink, G.W.W., Goedhart, P.W., Malinowska, A.H., Frissel, J.Y., Wegman, R.J.M., Slim, P.A., van Dobben, H.F., 2011. Ecological ranges for the pH and NO3 of syntaxa: A new basis for the estimation of critical loads for acid and nitrogen deposition. J. Veg. Sci. 22, 741-749. https://doi.org/10.1111/j.1654-1103.2011.01286.x

Wang, L., Watanabe, T., Xu, Z., 2015. Monetization of external costs using lifecycle analysis-A comparative case study of coal-fired and biomass power plants in Northeast China. Energies 
8, 1440-1467. https://doi.org/10.3390/en8021440

Wende, W., Tucker, G.-M., Quétier, F., Rayment, M., Darbi, M., 2018. Biodiversity Off sets. European Perspectives on No Net Loss of Biodiversity and Ecosystem Services. Springer, Cham, Switzerland.

Wichink Kruit, R.J., Aben, J., de Vries, W., Sauter, F., van der Swaluw, E., van Zanten, M.C., van Pul, W.A.J., 2017. Modelling trends in ammonia in the Netherlands over the period 19902014. Atmos. Environ. 154, 20-30. https://doi.org/10.1016/j.atmosenv.2017.01.031 


\section{Tables and figures}

Table 1. Power plant characteristics, nitrogen emission loads, eutrophication potential, nitrogen deposition in Natura 2000 areas $\left(\geq 0.05 \mathrm{Mol} \mathrm{N} \mathrm{ha}^{-1} \cdot \mathrm{yr}^{-1}\right)$, affected Natura 2000 area and calculated compensation area by power plants.

\begin{tabular}{|c|c|c|c|c|}
\hline Power plant & Plant 1 & Plant 2 & Plant 3 & Plant 4 \\
\hline Type & Thermal, CCGT & Thermal, CCGT & Thermal, CCGT & $\begin{array}{l}\text { Fluidized bed } \\
\text { boiler }\end{array}$ \\
\hline Fuel type & Conventional gas & Conventional gas & Conventional gas & $\begin{array}{l}\text { Renewable, } \\
\text { biomass }\end{array}$ \\
\hline Height emission source $(\mathrm{m})$ & 64 & 64 & 55 & 80 \\
\hline Installed capacity (MW) & $\begin{array}{l}\text { Electrical: } 248 \text {, } \\
\text { Thermal: } 180\end{array}$ & Electrical: 225 & $\begin{array}{l}\text { Electrical: } 870 \text {, } \\
\text { Thermal: } 180\end{array}$ & Electrical: 49.9 \\
\hline Electricity produced (MWh.year-1) & $1,062,645$ & 375,574 & $2,563,188$ & 367,286 \\
\hline Emission load $\left(\mathrm{kg} \mathrm{NO}_{\mathrm{x}} \cdot \mathrm{yr}^{-1}\right)$ & 365,138 & 133,046 & 243,204 & 22,720 \\
\hline$\left(\mathrm{kg} \mathrm{NH}_{4} \cdot \mathrm{yr}^{-1}\right)$ & - & - & 1,134 & 1,410 \\
\hline Eutrophication potential ( $\mathrm{PO}_{4}$-eq.) & 47,468 & 17,299 & 31,991 & 3,419 \\
\hline Nitrogen deposition (Mol N.ha-1. $\mathrm{yr}^{-1}$ ) & 90.08 & 19.60 & 67.10 & 0.84 \\
\hline Eutrophication efficiency ( $\mathrm{PO}_{4}$-eq. $\mathrm{MWh}^{-1}$ ) & 0.045 & 0.046 & 0.012 & 0.009 \\
\hline Affected area (ha) & 53,695 & 36,605 & 52,269 & 7,712 \\
\hline Relative affected area (ha. $\mathrm{PO}_{4-}$ eq. ${ }^{-1}$ ) & 1.13 & 2.12 & 1.63 & 2.26 \\
\hline Compensation area (ha) & 23.6 & 6.5 & 14 & 0 \\
\hline
\end{tabular}

Table 2. Regression coefficients of 1 /distance and average nitrogen deposition by power plants in Natura 2000 in the Netherlands.

\begin{tabular}{llllll}
\hline Power plant & $\mathrm{R}^{2}$ & \multicolumn{3}{c}{ Sum of Squares } & $\mathrm{F}$ \\
\cline { 3 - 4 } & & Regression & Residual & & \\
\hline Plant 1 & 0.487 & 0.461 & 0.487 & 100.50 & $<0.001$ \\
Plant 2 & 0.527 & 0.036 & 0.033 & 61.21 & $<0.001$ \\
Plant 3 & 0.871 & 1.442 & 0.213 & 710.77 & $<0.001$ \\
Plant 4 & - & & & & \\
\hline
\end{tabular}


Table 3. Pearson correlation coefficients between distance from power plant to Natura 2000 sites, relative share of power plant deposition to total deposition (Responsible share), exceedance of critical nitrogen loads of Nature 2000 habitat types (CDL exceedance) and affected surface area of Natura 2000 sites (Surface area). For each power plant the number of data points (Natura 2000 sites and habitat types included) is provided between brackets. ${ }^{*}=$ correlation is significant at the 0.05 level, and $* *=$ correlation is significant at the 0.01 level.

\begin{tabular}{llll}
\hline & Responsible share & CDL exceedance & Surface area \\
\hline plant 1 $(n=571)$ & $-0.246^{* *}$ & $0.030^{\text {ns }}$ & $-0.112^{* *}$ \\
plant 2 $(n=262)$ & $-0.468^{* *}$ & $0.055^{n s}$ & $-0.120^{\text {ns }}$ \\
plant 3 $(n=591)$ & $-0.595^{* *}$ & $0130^{* *}$ & $-0.047^{\text {ns }}$ \\
Plant 4 $(n=5)$ & - & - & - \\
\hline
\end{tabular}

Table 4. Regression estimates of nitrogen deposition by power plants (in Mol. ha-1 $\mathrm{yr}^{-1}$ ) and affected surface area (in ha) of vegetation types in Natura 2000 sites

\begin{tabular}{lllll}
\hline Power plant & $\mathrm{R}^{2}$ & Sum of squares & $\mathrm{F}$ & $\mathrm{P}$ \\
\hline Plant 1 & 0.053 & $8,281,732$ & 31.910 & $0.0001^{* * *}$ \\
Plant 2 & 0.052 & $7,545,706$ & 14.237 & $0.0001^{* * *}$ \\
Plant 3 & 0.002 & 317,872 & 1.224 & $0.269^{\text {ns }}$ \\
Plant 4 & - & - & - & - \\
\hline
\end{tabular}


Table 5. Nitrogen deposition and affected nature area per vegetation types in Germany and Belgium.

\begin{tabular}{|c|c|c|c|c|c|c|c|c|}
\hline \multirow[t]{2}{*}{ Vegetation type } & \multicolumn{4}{|c|}{ Nitrogen deposition ( Mol.ha-1. $\mathrm{yr}^{-1}$ ) } & \multicolumn{4}{|c|}{ Affected surface area (ha) } \\
\hline & Plant 1 & Plant 2 & Plant 3 & Plant 4 & Plant 1 & Plant 2 & Plant 3 & Plant 4 \\
\hline Dunes & - & - & - & 0.15 & - & - & - & 0.68 \\
\hline Fens & 3.00 & 0.41 & 1.35 & 0.09 & 152.02 & 30.98 & 147.69 & $<0.01$ \\
\hline Forest & 2.99 & 0.65 & 1.34 & 0.1 & 947.80 & 594.10 & 947.80 & $<0.01$ \\
\hline Grassland & 1.30 & 0.12 & 0.24 & 0.2 & 125.28 & 12.58 & 20.16 & $<0.01$ \\
\hline $\begin{array}{l}\text { Species-rich } \\
\text { grassland }\end{array}$ & 0.69 & - & 0.50 & 0.09 & 61.45 & - & 68.30 & $<0.01$ \\
\hline Heath & 1.03 & 0.37 & 0.43 & - & 20.13 & 20.13 & 20.13 & - \\
\hline Inland drift sand & 0.93 & 0.05 & 0.74 & - & 56.25 & 37.01 & 59.95 & - \\
\hline Quaking bogs & 1.90 & 0.47 & 0.88 & 0.2 & 28.06 & 19.48 & 27.67 & $<0.01$ \\
\hline Raised bogs & 0.11 & - & - & - & 2 & - & - & - \\
\hline Salt marches & 0.09 & - & - & - & 0.06 & - & - & - \\
\hline Swamp & 0.24 & - & 0.07 & - & 0.10 & - & 0.07 & - \\
\hline
\end{tabular}


Table 6. Average biodiversity footprint cost per power plant, calculated as $€ \cdot \mathrm{PO}_{4}-\mathrm{eq}^{-1} \cdot \mathrm{yr}^{-1}$ and $€ . \mathrm{MWh}^{-1} . \mathrm{yr}^{-1}$, separated by cost method (restoration, insetting, offsetting).

\begin{tabular}{llll}
\hline Cost estimate & Plant 1 & Plant 2 & Plant 3 \\
\hline Restoration & 3.85 & 2.22 & 5.15 \\
$€ . \mathrm{PO}_{4}-\mathrm{eq}^{-1} \cdot \mathrm{yr}^{-1}$ & 0.17 & 0.10 & 0.06 \\
$€ . \mathrm{MWh}^{-1} \cdot \mathrm{yr}^{-1}$ & & & \\
Insetting & 14.82 & 12.66 & 9.92 \\
$€ . \mathrm{PO}_{4}-\mathrm{eq}^{-1} \cdot \mathrm{yr}^{-1}$ & 0.66 & 0.58 & 0.12 \\
$€ . \mathrm{MWh}^{-1} \cdot \mathrm{yr}^{-1}$ & & & \\
Offsetting & 36.94 & 30.85 & 24.89 \\
$€ . \mathrm{PO}_{4}-\mathrm{eq}^{-1} \cdot \mathrm{yr}^{-1}$ & 1.65 & 1.42 & 0.31 \\
$€ . \mathrm{MWh}^{-1} \cdot \mathrm{yr}^{-1}$ & &
\end{tabular}




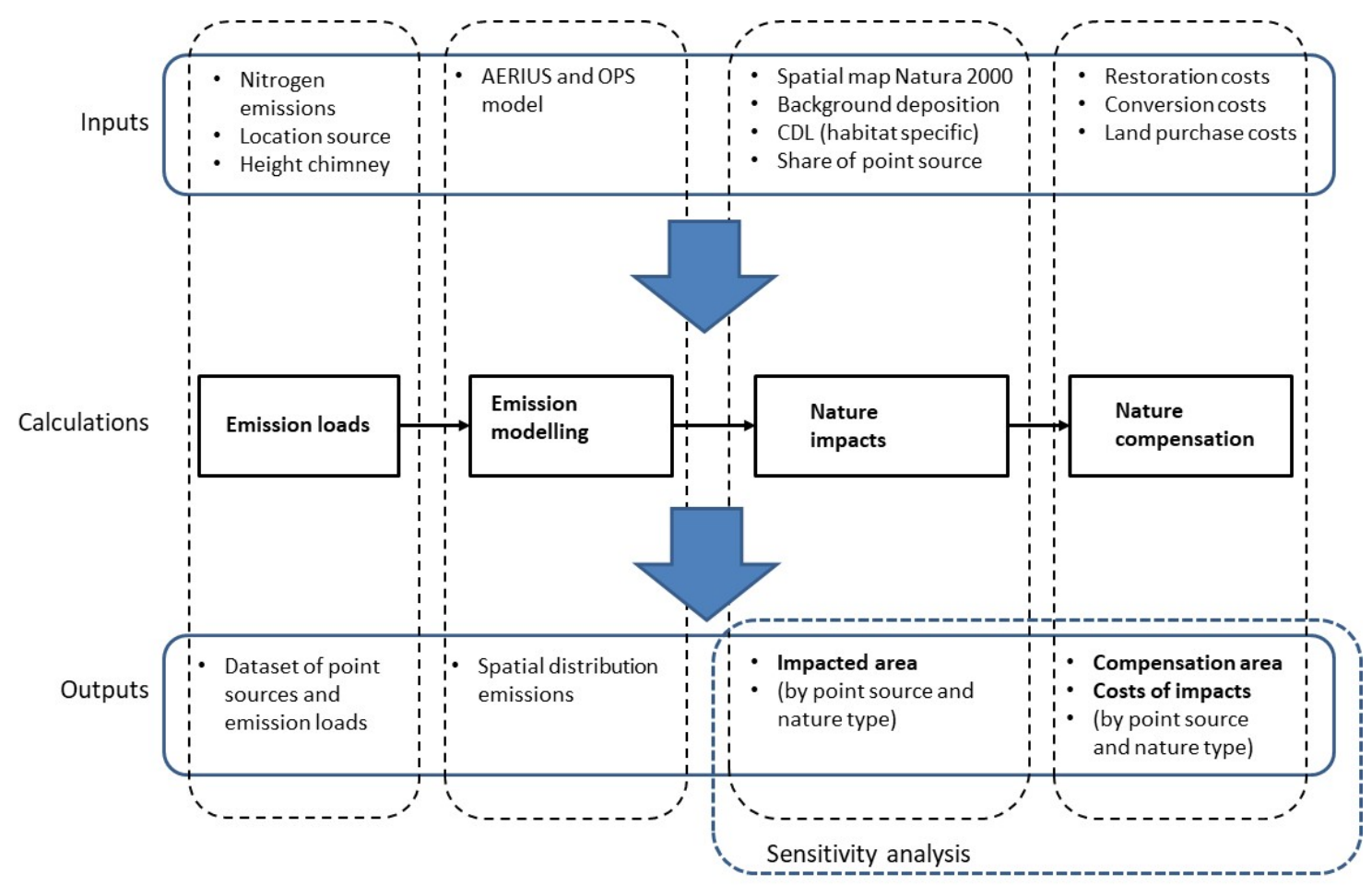

Figure 1. Analytical framework used to estimate biodiversity impacts and compensation costs of nitrogen emissions 


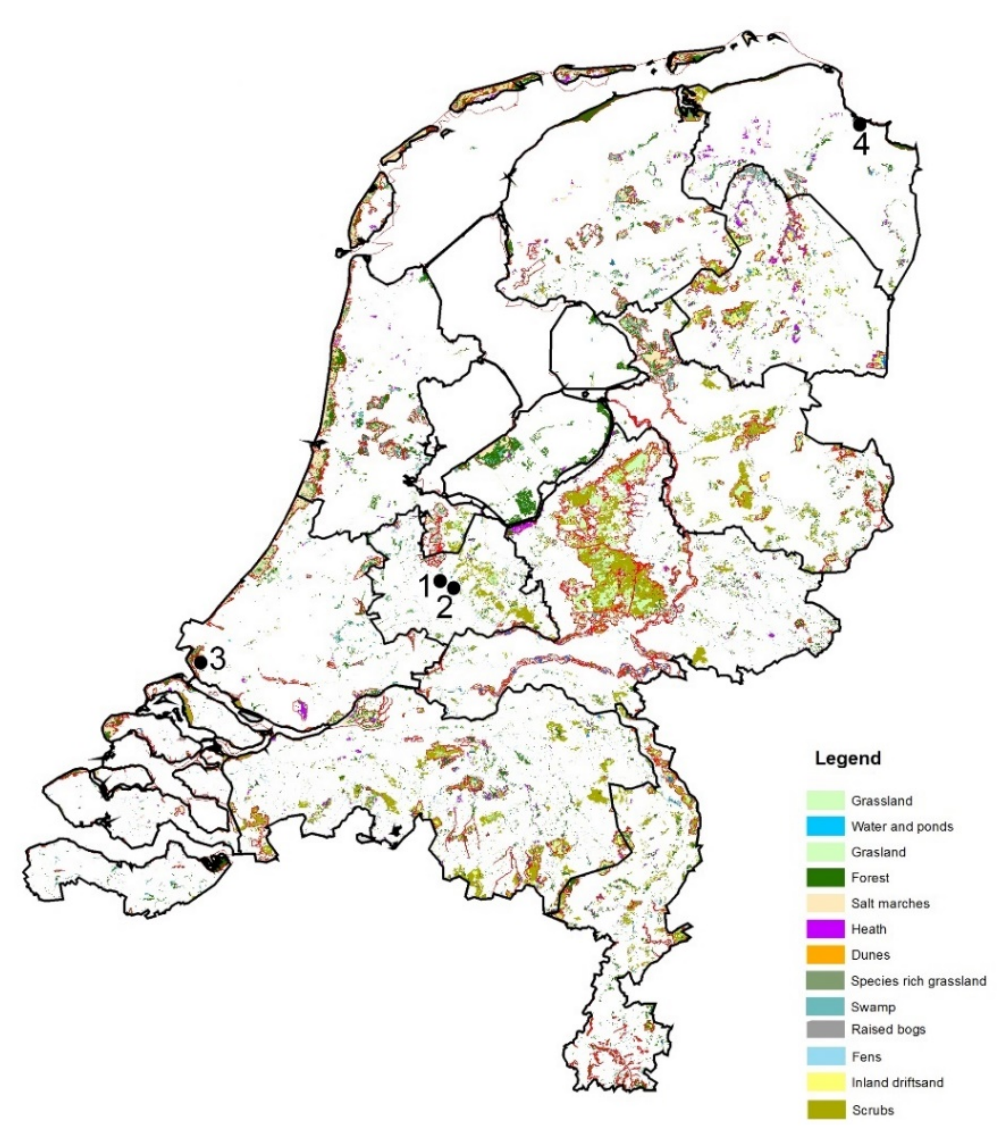

Figure 2. Location of power plants 1-4 and main land cover types of Natura 2000 sites in the Netherlands. Land cover data derived from the Netherlands Environmental Assessment Agency (PBL). 


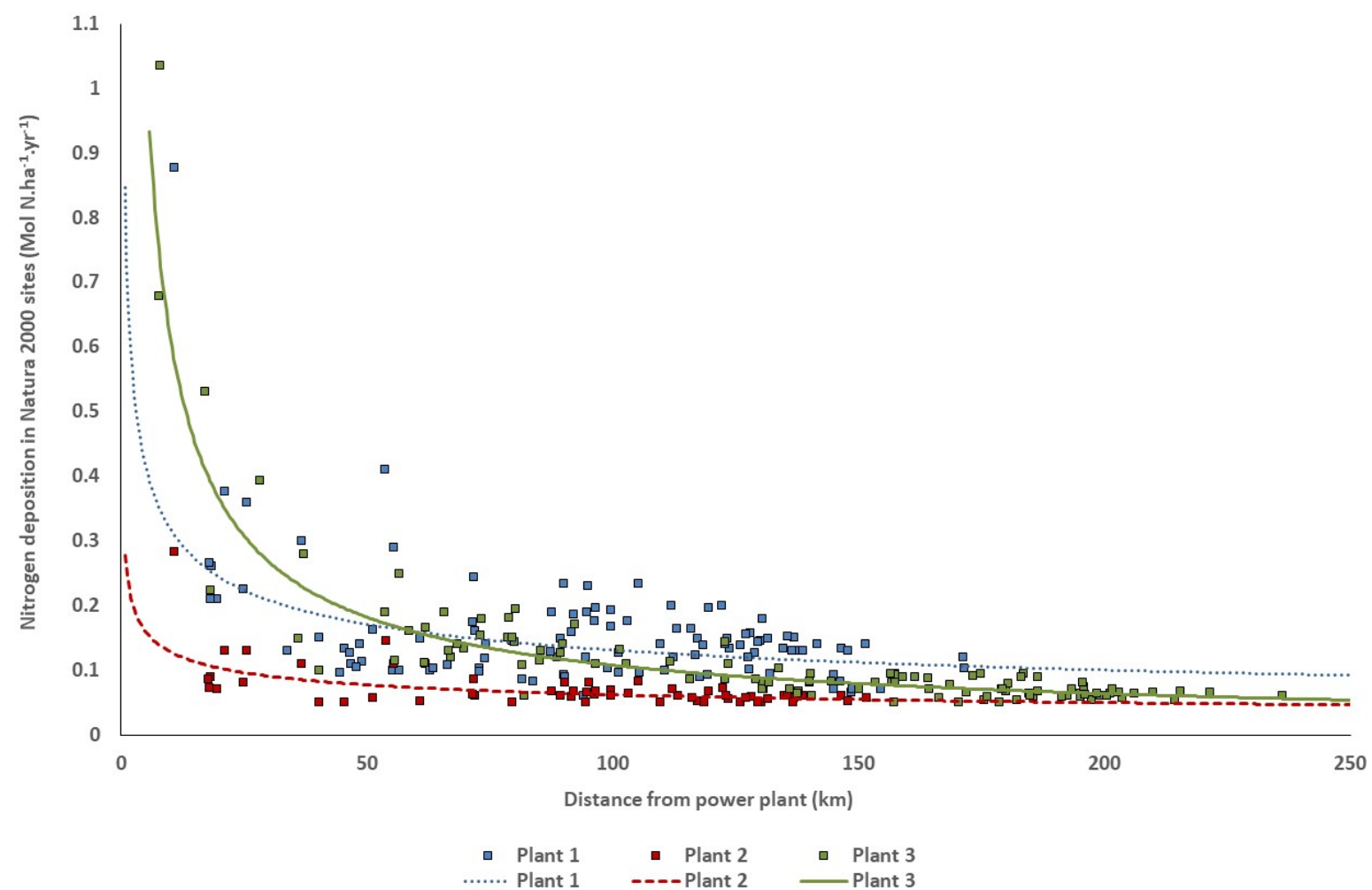

Figure 3. Relationship between nitrogen deposition in Natura 2000 areas at $>0.05 \mathrm{Mol} \mathrm{N}$. ha-1. $\mathrm{yr}^{-1}$ and distance from power plants $(\mathrm{km})$. For characteristics of power plants, see Table 1. 

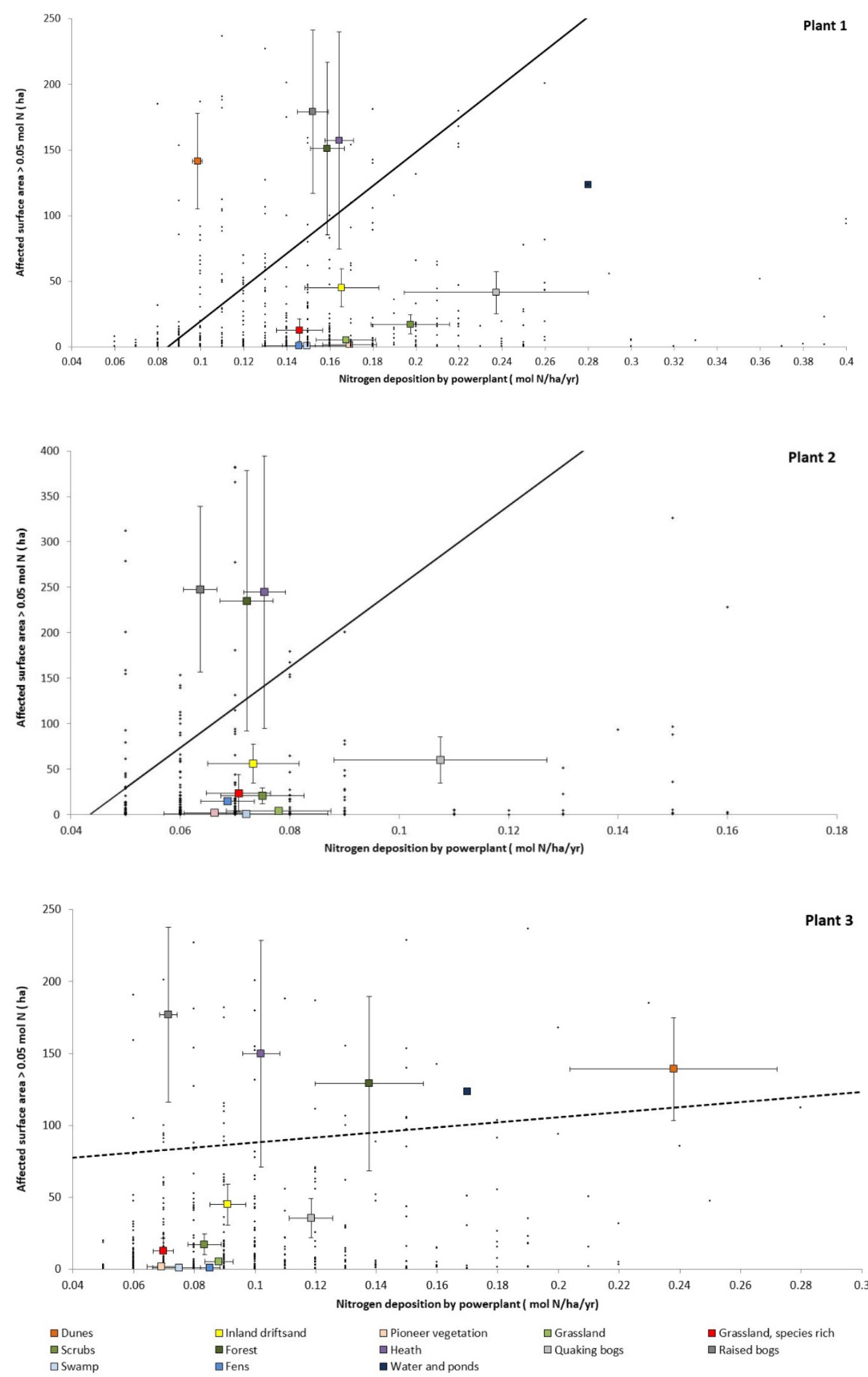

Figure 4. Affected surface areas of habitat types within Natura 2000 sites by the share of nitrogen deposition of Power plants 1 - 3. Data of Plant 4 not shown. Small dots indicate individual habitat types within Natura 2000 sites, and coloured symbols indicate the average values ( \pm SE) of grouped vegetation types. Solid lines are significant regressions, and the dotted line (Plant 3 ) is a non-significant regression (see Table 4 for regression estimates). See supplementary material for habitat types grouping to generic vegetation types. 


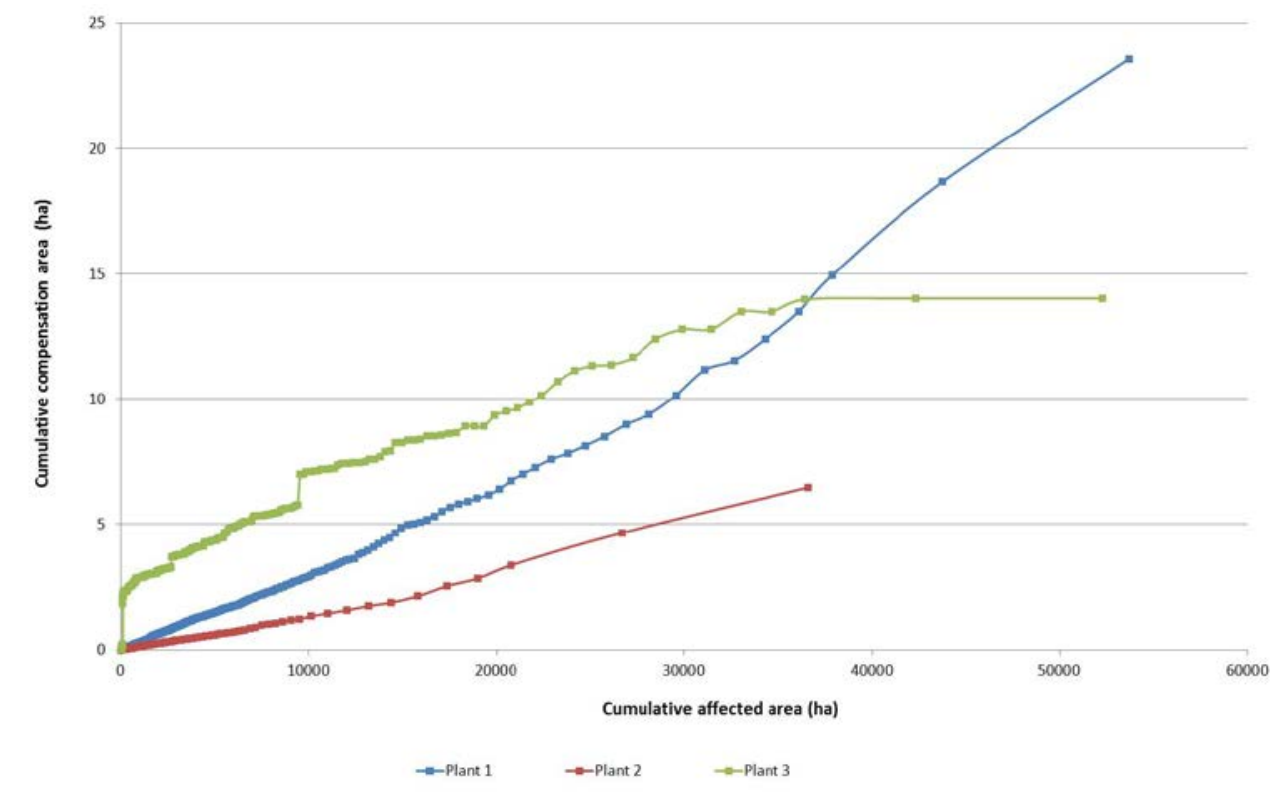

Figure 5. Curves of cumulative compensation area in relation to cumulative area affected by nitrogen deposition from Power plants 1-3. Data points are arranged in increasing order according to affected area. 

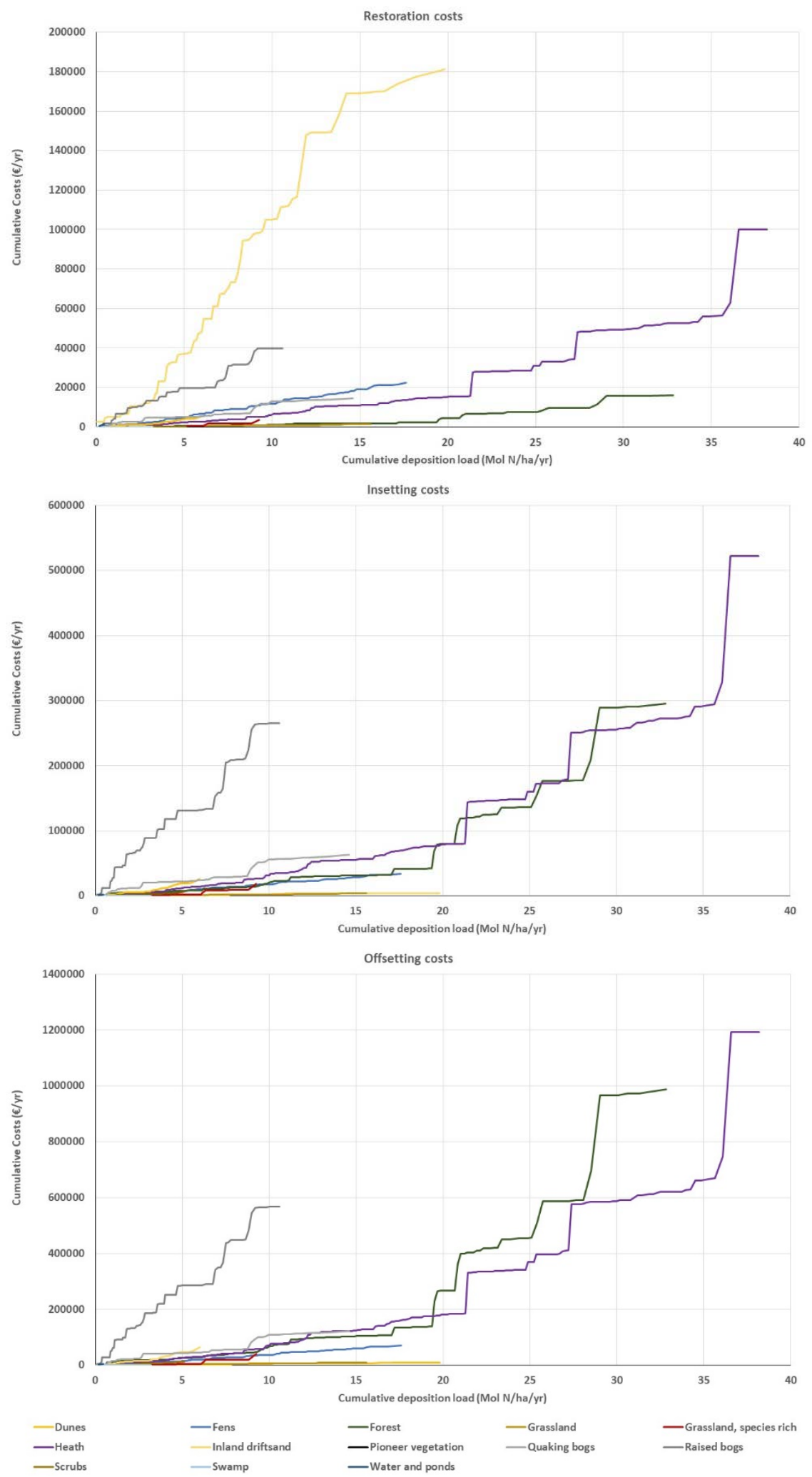

Figure 6. Cumulative cost curves related to cumulative nitrogen deposition of Power plants 1-3 for restoration, 'insetting' and offsetting cost estimates. 

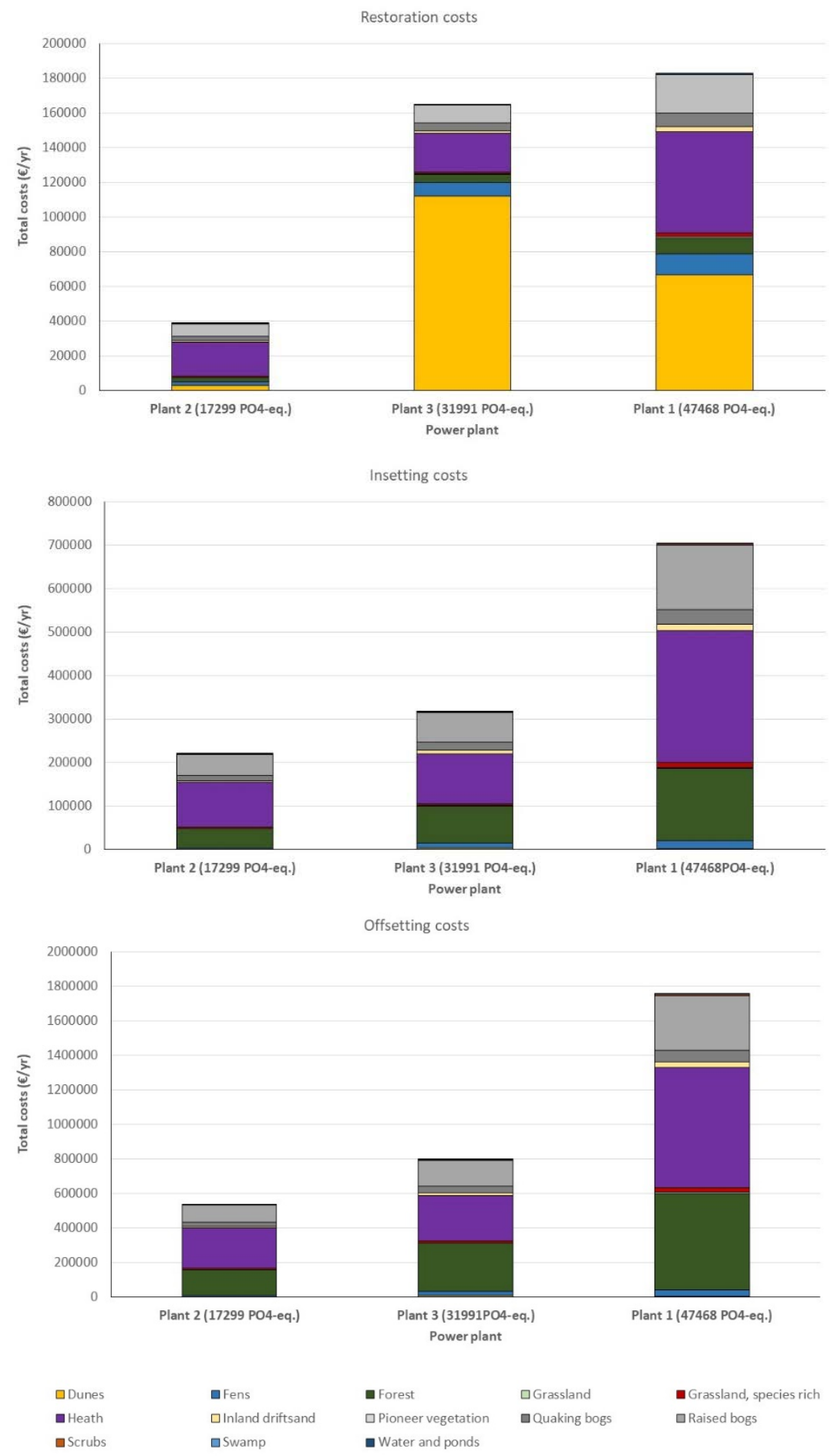

Figure 7. Total restoration, 'insetting' and offsetting cost estimates related to nitrogen deposition per power plant, broken down by vegetation type. Power plants are arranged according to eutrophication potential ( $\mathrm{PO}_{4}$-eq.). 


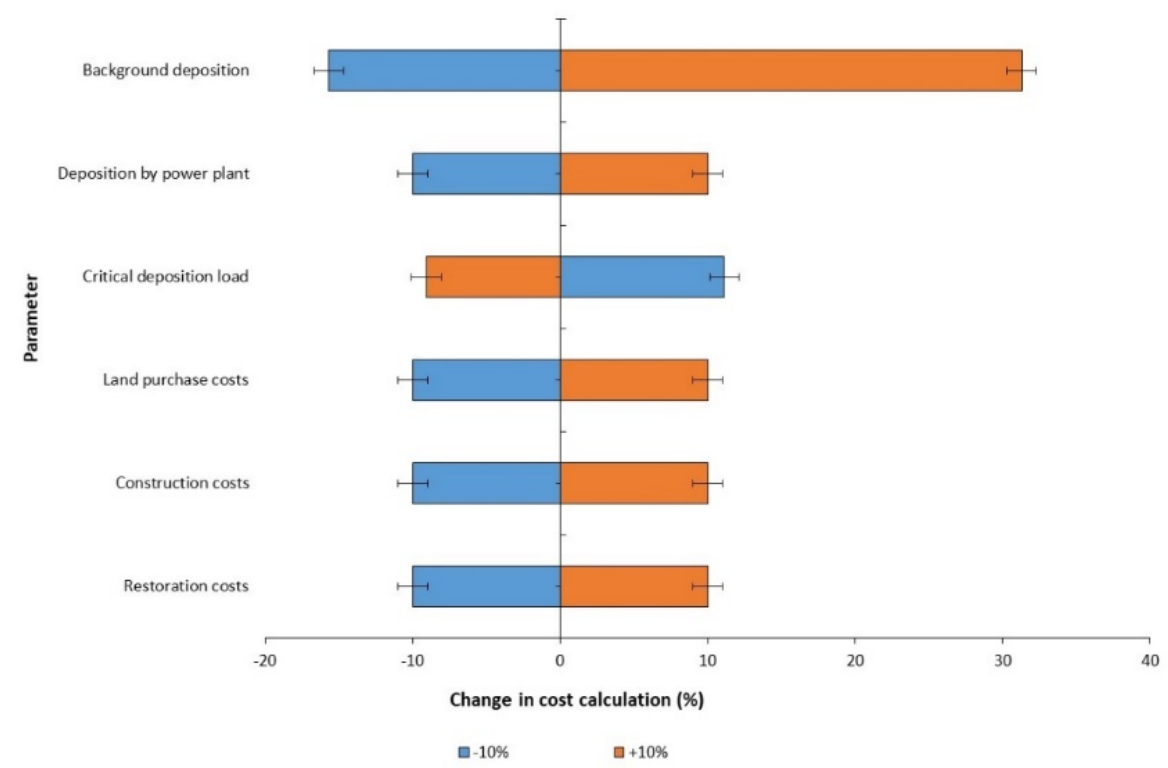

Figure 8 . Results of the sensitivity analysis based on $-10 \%$ or $+10 \%$ changes in input parameter values, depicted as relative differences from the baseline cost estimates. 